\title{
Pengaruh Kebijakan Pembelajaran pada Masa Pandemi Covid-19 terhadap Efikasi Diri dan Perilaku Belajar Siswa
}

\author{
Suryono $^{1]}$, Adolf Bastian ${ }^{2]}$, Fahmi Oemar ${ }^{3]}$ \\ Universitas Lancang Kuning \\ E-mail: ${ }^{1]}$ suryonokokokiki@gmail.com \\ 2]abtambusai@yahoo.com \\ ${ }^{3]}$ fahmi_pala@yahoo.com
}

\begin{abstract}
Abstrak
Kebijakan pembelajaran pada masa pandemi berbeda dengan keadaan normal. Efikasi diri dan perilaku belajar siswa pun juga sangat berbeda. Kedua poin ini sangat menarik untuk dikaji mendalam. Dalam penelitian ini, tujuan penelitian ini adalah untuk menganalisis pengaruh kebijakan pembelajaran terhadap efikasi diri dan perilaku belajar siswa. Penelitian ini menggunakan pendekatan kuantitatif dengan metode survei. Sampel yang terlibat adalah sebanyak 89 siswa Sekolah Menengah Kejuruan (SMK) Negeri 1 Pekanbaru. Pengambilan sampel dilakukan secara acak sederhana. Data penelitian diperoleh melalui penyebaran kuesioner dan dianalisis dengan menggunakan analisis jalur (path analysis) yang didukung analisis statistik deskriptif. Hasil penelitian ini menunjukkan bahwa kebijakan pembelajaran berpengaruh langsung terhadap perilaku belajar, efikasi diri berpengaruh langsung positif dan sangat signifikan terhadap perilaku belajar, dan kebijakan pembelajaran berpengaruh langsung positif dan sangat signifikan terhadap efikasi diri. Selain itu, kebijakan pembelajaran berpengaruh tidak langsung positif dan sangat signifikan terhadap perilaku belajar dengan mediasi efikasi diri. Oleh karena itu, perbaikan kebijakan pembelajaran dapat meningkatkan efikasi diri dan perilaku belajar siswa, sehingga pimpinan sekolah perlu menyesuaikan kebijakan pembelajaran sesuai kebutuhan dan kondisi aktual internal dan eksternal sekolah. Selain itu, efikasi diri siswa juga perlu ditingkatkan secara berkelanjutan melalui berbagai penguatan, misalnya supervisi, konseling, dan pemberian reward bagi siswa yang berprestasi. Sebagai saran untuk penelitian lanjutan, konsekuensi teoretik hasil penelitian juga perlu dilakukan dengan sampel berbeda dengan jumlah lebih besar serta menggunakan teknik analisis yang berbeda, misalnya Stuctutral Equation Modeling (SEM).
\end{abstract}

Kata kunci: kebijakan pembelajaran, efikasi diri, perilaku belajar

\section{The Effect of Learning Policies during the Covid-19 Pandemic on Students' Self-Efficacy and Learning Behavior}

\begin{abstract}
Learning policies during a pandemic are different from normal conditions. Students' self-efficacy and learning behavior are also very different. These two points are very interesting to be studied in depth. In this research, the aim is to analyze the effect of learning policies on self-efficacy and student learning behavior. This research uses a
\end{abstract}


quantitative approach with a survey method. The sample used was 89 students of SMK Negeri 1 Pekanbaru. Sampling was done by simple random. The research data was obtained by distributing questionnaires and analyzed using path analysis supported by descriptive statistical analysis. This study indicated that learning policies had a direct effect on learning behavior. Self-efficacy had a direct positive and very significant effect on learning behavior. Learning policies had a direct positive and very significant effect on self-efficacy. In addition, learning policies had a positive and very significant indirect effect on learning behavior by mediating self-efficacy. Therefore, improvement of learning policies could increase students' self-efficacy and learning behavior, so school leaders need to adjust learning policies according to the needs and actual conditions of internal and external schools. In addition, student self-efficacy also needs to be continuously improved through various reinforcements, such as supervision, counseling, and giving rewards for outstanding students. As suggestion for further research, consequence of the theoretical results of the research also needs to be carried out with different samples with a larger number and using different analytical techniques, such as structural equation modeling (SEM).

Keywords: Learning policy, self-efficacy, learning behavior

\section{PENDAHULUAN}

Saat ini di seluruh dunia, termasuk Indonesia, mengalami wabah coronavirus disease yaitu virus corona atau sering disebut Covid-19. Negara di seluruh dunia diminta oleh WHO (World Health Organization) termasuk Indonesia agar mengambil suatu tindakan yang mendesak dan agresif untuk ikut mencegah dan mengendalikan Covid-19. Pemerintah Indoneisa mengeluarkan suatu kebijakan guna menekan angka kejadian Covid-19 melalui penerapan protokol kesehatan yakni jaga jarak (physical distancing atau social distancing), cuci tangan dan memakai masker, hingga hingga pembatasan sosial berskala besar (PSBB).

Kebijakan pemerintah tersebut mengakibatkan sektor pendidikan seperti sekolah maupun perguruan tinggi menghentikan proses pembelajaran secara tatap muka. Dengan demikian sebagai gantinya, proses pembelajaran dilaksanakan

Menurut Mendikbud Nadiem Anwar Makarim (GTK
Kemendikbudristek, 2020), prinsip kebijakan pendidikan di masa pandemi Covid-19 adalah mengutamakan kesehatan dan keselamatan peserta didik, pendidik, tenaga kependidikan, keluarga, dan masyarakat secara umum, serta mempertimbangkan tumbuh kembang peserta didik dan kondisi psikososial dalam upaya pemenuhan layanan pendidikan selama pandemi Covid-19. Melalui sejumlah fasilitas tersebut para pengajar (baik guru, murid maupun dosen dan mahasiswanya) dapat melakukan pembelajaran bersama di waktu yang sama menggunakan platform online.

Kondisi pembelajaran dalam jaringan (daring), untuk mengetahui perilaku belajar siswa merupakan hal yang penting. Perilaku belajar dapat dipengaruhi oleh faktor intern dan ekstern. seperti kesehatan dan cacat tubuh. Proses belajar seseorang akan terganggu jika kesehatannya terganggu, selain itu juga ia akan cepat lelah, kurang bersemangat, mudah pusing, ngantuk jika badannya lemah. Faktor psikologis seperti intelegensi, perhatian, 
minat, bakat, motif, kematangan dan kesiapan. Faktor kelelahan meliputi kelelahan jasmani dan kelelahan rohani (bersifat psikis). Sementara faktor ekstern meliputi keluarga, sekolah, dan masyarakat. Perilaku belajar siswa mempunyai keterkaitan dengan prestasi belajar, sebab dalam perilaku belajar mengandung kebiasaan belajar dan cara-cara belajar yang dianut siswa. Perilaku belajar yang baik akan berpengaruh pada hasil belajar yang baik pula.

Namun, dalam kenyataannya, pembelajaran daring pada masa pandemi Covid-19 masih banyak siswa yang hasil belajarnya rendah. Kondisi ini tentu tidak terjadi begitu saja melainkan ada penyebabnya. Sejumlah faktor yang dapat mempengaruhinya adalah adanya pemberlakuan kebijakan pembelajaran dimasa pandemi Covid-19 dan efikasi diri pada siswa. Pertama, kebijakan pembelajaran merupakan upaya atau tindakan untuk mempengaruhi sistem pencapaian tujuan yang diinginkan berdasarkan waktu panjang dan menyeluruh untuk memberikan bimbingan melalui proses mengatur, mengorganisasi, menumbuhkan, serta mendorong peserta didik guna melakukan proses belajar. Jika kebijakan pembelajaran yang diberikan siswa SMK Negeri 1 Pekanbaru dimasa pandemi Covid-19 ini tercermin dalam sejumlah aspek tersebut terkondisikan dengan baik maka hal ini akan menstimulus peningkatan perilaku belajar. Sebagaimana ditunjukkan dalam penelitian Suryaningsih dan Poerwati (2021), Hendrayani dan Arief (2018), Jamil dan Aprilisanda (2020), serta Jusuf dkk., (2020) yang membuktikan bahwa kebijakan pembelajaran memiliki pengaruh terhadap perilaku belajar.
Kedua, efikasi diri (self-efficacy), yakni perasaan mampu menggerakkan motivasi, sumber daya kognitif, dan cara bertindak yang diperlukan untuk berhasil melaksanakan tugas tertentu, yang tercermin dalam sejumlah dimensi tingkatan/besaran, kekuatan, dan generalitas. Tumbuhnya efikasi diri merupakan salah satu aspek yang berpengaruh dalam keberhasilan menghadapi tuntutan kehidupan. Siswa yang memiliki efikasi diri akan tetap bertahan dalam menghadapi hambatan atau tantangan yang diberikan. Oleh karenanya setiap siswa dituntut memiliki efikasi diri sebagai salah satu upaya dalam mewujudkan tujuan pendidikan. Ketika efikasi diri siswa SMK Negeri 1 Pekanbaru dalam kondisi baik seperti terlihat dalam tingkatan/besaran, kekuatan, dan generalitas, maka hal itu berdampak pada peningkatan perilaku belajar siswa, walaupun dalam masa pandemi Covid-19. Hal ini sesuai dengan hasil penelitian yang dilakukan Pratiwi dan Hayati (2021), Ningsih dan Hayati (2020), Yoenanto (2017), Witurrachmi dan Hamidi (2017) yang menunjukkan bahwa efikasi diri memiliki pengaruh terhadap perilaku belajar siswa.

Berdasarkan uraian di atas, maka fenomena tersebut menarik untuk diteliti secara ilmiah dalam bentuk tesis dengan judul: "Pengaruh kebijakan pembelajaran pada masa pandemi Covid-19 terhadap efikasi diri dan perilaku belajar siswa SMK Negeri 1 Pekanbaru."

\section{Perumusan Masalah}

Berdasarkan pembatasan masalah tersebut, maka rumusan masalah penelitian ini adalah sebagai berikut.

1. Apakah kebijakan pembelajaran berpengaruh langsung terhadap perilaku belajar siswa SMK Negeri 1 Pekanbaru? 
2. Apakah kebijakan pembelajaran berpengaruh langsung terhadap efikasi diri siswa SMK Negeri 1 Pekanbaru?

3. Apakah efikasi diri berpengaruh langsung terhadap perilaku belajar siswa SMK Negeri 1 Pekanbaru?

4. Apakah kebijakan pembelajaran berpengaruh tidak langsung terhadap perilaku belajar siswa SMK Negeri 1 Pekanbaru dengan mediasi efikasi diri?

\section{Kebijakan Pembelajaran}

Istilah kebijakan pembelajaran dapat diartikan secara komprehensif dengan terlebih dahulu menjelaskan pengertian kebijakan dan dikuti pengertian pembelajaran. Kebijakan ialah cetak biru bagi tindakan yang mengarah dan mempengaruhi perilaku orang banyak yang terkena dampak keputusan tersebut. Di dalam kebijakan terkadung tujuan yang ingin dicapai yang berpihak kepada kepentingan masyarakat (Suwitri, 2014). Selain itu kebijakan memiliki sejumlah unsur yang memberikan pemahaman tentang alasan mengapa kebijakan tersebut perlu untuk ada. Salah satu unsur terpenting dari kebijakan adalah tujuan kebijakan (Handoyo, 2012).

Di samping itu Siswanto dkk (2016) mengatakan bahwa transparansi dalam suatu kebijakan adalah dasar yang dapat menjamin keleluasaan bagi seluruh masyarakat dalam rangka mendapatkan informasi yang berkaitan dengan pelaksanaan pemerintahan, juga keterbukaan implementor dalam menciptakan kebijakan. Kebijakan perlu implementasi di lapangan. Sebagus apapun kebijakan jika tidak diimplementasikan, tidak ada gunanya. Untuk mengimplementasikan kebijakan publik, maka ada dua pilihan langkah yang ada yaitu langsung mengimplementaiskan dalam bentuk program-program atau melalui formulasi kebijakan derivat atau turunan dari kebijakan publik tersebut (Nugroho, 2014).

Kemudian perihal pembelajaran pada hakikatnya adalah suatu proses mengatur, mengorganisasi lingkungan yang ada disekitar peserta didik, sehingga dapat menumbuhkan dan mendorong peserta didik untuk melakukan proses belajar. Pembelajaran juga dikatakan sebagai proses memberikan bimbingan atau bantuan kepada peserta didik dalam melakukan proses belajar. Pembelajaran adalah proses interaksi peserta didik dengan pendidik, dengan bahan pelajaran, metode penyampaian, strategi pembelajaran, dan sumber belajar dalam suatu lingkungan belajar (Pane dan Dasopang, 2017).

Di dalam Undang-undang Republik Indonesia Nomor 20 tahun 2003 tentang Sistem Pendidikan Nasional, dijelaskan bahwa pembelajaran adalah proses interaksi pendidik dengan peserta didik dan sumber belajar yang berlangsung dalam suatu lingkungan belajar. Secara nasional, pembelajaran dipandang sebagai suatu proses interaksi yang melibatkan komponen-komponen utama, yaitu peserta didik, pendidik, dan sumber belajar yang berlangsung dalam suatu lingkungan belajar, maka yang dikatakan dengan proses pembelajaran adalah suatu system yang melibatkan satu kesatuan komponen yang saling berkaitan dan saling berinteraksi untuk mencapai suatu hasil yang diharapkan secara optimal sesuai dengan tujuan yang telah ditetapkan (Pane dan Dasopang, 2017).

Pembelajaran, disebutkan juga kegiatan pembelajaran atau instruksional adalah usaha mengelola lingkungan dengan sengaja agar seseorang membentuk diri secara positif 
tertentu dalam kondisi tertentu. Sedangkan pengajaran adalah usaha membimbing dan mengarahkan pengalaman belajar kepada peserta didik yang biasanya berlangsung dalam situasi resmi/formal.

Hakikat pembelajaran ialah suatu proses, yaitu proses mengatur, mengorganisasi lingkungan yang ada di sekitar peserta didik sehingga dapat menumbuhkan dan mendorong peserta didik melakukan proses belajar. Pembelajaran juga dikatakan sebagai proses memberikan bimbingan atau bantuan kepada peserta didik dalam melakukan proses belajar. Dengan demikian hakikat dari pembelajaran adalah pengaturan. Pada hakikatnya, pembelajaran dalam makna kompleks adalah usaha sadar dari seorang guru untuk membelajarkan peserta didiknya (mengarahkan interaksi peserta didik dengan sumber belajar lain) dengan maksud agar tujuannya dapat tercapai. Definisi ini memperlihatkan dengan jelas bahwa pembelajaran itu merupakan interaksi dua arah dari pendidik dan peserta didik, diantara keduanya terjadi komunikasi yang terarah menuju kepada target yang telah ditetapkan.

Pembelajaran dapat dilakukan tanpa tata muka atau yang lazim disebut pembelajaran jarak jauh (PJJ). Menurut Rahmawati (2020), pembelajaran jarak jauh (PPJ) adalah pembelajaran yang menekankan pada cara belajar mandiri. Belajar mandiri diorganisasikan secara sistematis dalam menyajikan materi pembelajaran, pemberian bimbingan kepada pembelajaran dan pengawasan untuk keberhasilan belajar mengajar.

Pembelajaran jarak jauh merupakan suatu proses pembelajaran tidak terjadi kontak dalam bentuk tatap muka langsung antara pengajar dan pembelajar. Komunikasi berlangusng dua arah yang dijembatani dengan media seperti komputer, televisi, radio, telepon, internet, video dan sebagainya (Munir, 2012). Pembelajaran jarak jauh bersifat fleksibel dan dapat diakses dimana saja dan kapan saja. Banyak media yang menunjang pembelajaran jarak jauh seperti e-learning yang memanfaatkan teknologi dalam menjangkaunya.

Menurut Munir (2012), pembalajaran jarak jauh memiliki sejumlah karakteristik, yakni: (1) program disusun disesuaikan jenjang, jenis dan sifat pendidikan; (2) dalam proses pembelajaran tidak ada pertemuan langsung secara atap muka anatar pengajar dan pembelajar sehingga tidak ada kontak langsung antara pengajar dengan pembelajar; (3) pembelajar dan pengajar terpisah sepanjang proses pembelajaran itu karena tidak ada attap muka seperti halnya dalam pembelajaran konvensional, sehingga pembelajaran harus dapat belajar secara mandiri; (4) adanya lembaga pendidikan yang mengatur pembelajaranuntuk belajar mandiri, pendidikan jarak jauh adalah sistem pendidikan yang menekankan pada cara belajat mendiri; (5) lembaga pendidikan merancang dan menyiapkan materi pembelajaran serta memberikan pelayanan bantuan belajar kepada pembelajar; (6) materi pembelajaran disampaikan melalui media pembelajaran, seperti computer dengan interentnya atau dengan program $e$ learning; (7) melalui media pembelajaran tersebut akan terjadi komunikasi dua arah antara pembelajaran dan pengajar, pembelajaran dengan pembelajar lain atau pembelajar dengan lembaga penyelenggaraan pembelajaran jarak jauh; (8) tidak ada kelompok belajar yang berisfat tetap sepanjang masa belajarnya,karena itu pembelajar menerima pembelajaran secara individu 
bukannya secara kelompok; (9) paradigm baru yang terjadi dalam pembelajaran jarak jauh adalah peran pengajar yang lebih bersifat fasilitator yang memberikan bantuan atau kemudahan kepada pembelajar untuk belajar, dan pembelajar sebagai peserta dalam proses pembelajar; (10) pembeajar dituntut aktif, dan pratisipatif dalam proses belajar karena kebutuhan dengan tatap muka berdasarkan kurikulum; (11) interaksi pembelajaran bisa dilaksanakan secara langsung jika ada suatu pertemuan.

Yerusalem dkk. (2020) menyebutkan sejumlah ragam pembelajaran jarak jauh seperti: (1) belajar mandiri; (2) belajar terbimbing atau terstruktur; (3) tutorial tata muka: proses pembelajaran jarak jauh dilaksanakan dengan mempersyaratkan adanya tutorial atau pembimbing tatap muka langsung (atau termediasi sinkron) kepada peserta didik beragam mata kuliah; (4) tutorial elektronik; (5) bantuan lainnya (koresponden, telpon, dan faksimile).

\section{Efikasi Diri}

Efikasi diri (self-efficacy) dimiliki oleh setiap orang, dan diperlukan dalam bekerja sebagai modal guna memicu aktivitas kerjanya agar dapat menyelesaikan tugas atau pekerjaan dengan baik dan berkualitas. Efikasi diri merupakan hal yang penting untuk dimiliki siswa yang ditandai dengan hadirnya keyakinan pada diri sendiri bahwa dirinya dapat menguasai situasi yang dihadapi dan menghasilkan kinerja yang diharapkan. Efikasi diri merupakan keyakinan diri individu terhadap kemampuan dirinya sendiri pada suatu tugas atau konteks yang spesifik (task-spesific) yang berpengaruh kuat terhadap perilaku dan outcome individu (Permatasari dkk., 2021).
Di dalam efikasi diri terdapat sejumlah faktor yang dapat diidentifikasi oleh Luthans (2013) sebagai berikut.

1. Physiological and psychological arousal (kebangkitan fisiologi dan psikologi).

Untuk menilai kemampuannya, seseorang sering dipengaruhi oleh perasaan fisik dan emosi. Jika perasaan dan emosi seseorang negatif, maka hal ini akan mempengaruhi efikasi dirinya. Di sisi lain, jika kondisi fisik dan mental baik, hal ini bisa berfungsi sebagai titik tolak untuk membangun efikasi diri membangkitkan kemampuan seseorang untuk meneyelesaikan tugas yang menuntut kemampuan fisik dan/atau psikis.

2. Vicarious experiences or modeling (pengalaman sendiri atau peniruan). Peniruan dan pemodelan mempunyai peran penting. Jika seseorang melihat orang lain yang setara dengan dirinya bisa berhasil dalam usahanya, orang tersebut akan merasa yakin bahwa dirinya juga memiliki kemampuan untuk berhasil. Sebaliknya, mengamati kegagalan orang lain akan memunculkan keraguan tentang kemampuannya untuk menguasai aktivitas serupa. Semakin serupa atau setara model itu secara demografis seperti: usia, jenis kelamin, sifat-sifat fisik, dan pendidikan serta status dan pengalaman dengan dirinya, maka akan semakin yakin dirinya dapat melaksanakan tugas dengan baik.

3. Mastery experiences or performance attainments (penguasaan pengalaman atau prestasi kerja yang dicapai).

Faktor ini merupakan unsur paling kuat untuk membentuk keyakinan 
kemampuan karena merupakan informasi langsung tentang keberhasilan. Proses situasi, yaitu kerumitan tugas dan pemahaman, yaitu persepsi kemampuan seseorang mengenai kerja juga memengaruhi penilaian efikasi diri dan keyakinannya. Penguasaan pengalaman yang diperoleh lewat usaha keras dan kemampuan belajar merupakan pandangan kemampuan yang kuat dan bertahan, tetapi kemampuan yang dibangun dari keberhasilan yang muncul dengan mudah tidak bisa ditandai dengan banyak kegigihan ketika kesulitan muncul dan akan berubah lebih cepat.

4. Social persuasion (bujukan sosial).

Keyakinan orang pada kemampuannya dapat diperkuat oleh dorongan atau bujukan orang lain bahwa dirinya dapat melakukan apa yang diperlukan dan akan memberikan hasil positif dan kemajuan. Di sisi lain, terdapat pengaruh kuat dari kata-kata negatif yang bisa menurunkan kepercayaan seseorang. Komentar negatif atau gerakan non-verbal yang bermakna negatif akan berdampak luas pada gejolak emosi dan kemampuan seseorang. Persuasi sosial bisa dipilih dan diolah untuk membangun keyakinan akan kemampuan. Persuasi sosial ini menjadi semakin penting untuk mengisi celah ketika orang mulai meragukan dirinya.

Berdasarkan uraian di atas dapat disintesiskan bahwa efikasi diri (selfefficacy) adalah perasaan mampu menggerakkan motivasi, sumber daya kognitif, dan cara bertindak yang diperlukan untuk berhasil melaksanakan tugas tertentu, yang diukur berdasarkan indikator: (1) tingkatan/besaran, (2) kekuatan, dan (3) generalitas.

\section{Perilaku Belajar}

Istilah perilaku belajar dapat diartikan secara komprehensif dengan terlebih dahulu menjelaskan pengertian perilaku dan diikuti pengertian belajar. Sebutan perilaku (behavior) atau disebut sikap ialah semua aktivitas yang dilakukan manusia pada umunya, dan mengandung makna yang luas. Perilaku belajar dapat diartikan sebagai sebuah aktivitas belajar. Konsep dan pengertian belajar sendiri sangat beragam, tergantung dari sisi pandang setiap orang yang mengamatinya.

Dari pengertian ini dapat diketahui bahwa perubahan tingkah laku yang timbul akibat proses kematangan, keadaan gila, mabuk, lelah, dan jenuh tidak dapat dipandangsebagai proses belajar.

Aunurrahman (2013) menjelaskan bahwa belajar menunjukkan aktivitas yang dilakukan oleh seseorang yang disadari atau disengaja. Aktivitas ini menunjuk pada keaktifan seseorang dalam melakukan aspek mental yang memungkinkan terjadinya perubahan pada dirinya. Dengan demikian, dapat dipahami juga bahwa suatu kegiatan belajar dikatakan baik apabila intensitas keaktifan jasmani maupun mental seseorang semakin tinggi. Sebaliknya meskipun seseorang dikatakan belajar, namun jika keaktifan jasmaniah dan mentalnya rendah berarti kegiatan belajar tersebut tidak secara nyata memahami bahwa dirinya melakukan kegiatan belajar.

Belajar dimaknai sebagai proses perubahan perilaku sebagai hasil interaksi individu dengan lingkungannya. Perubahan perilaku terhadap hasil belajar bersifat kontiniu, fungsional, positif, aktif, dan terarah. Proses perubahan tingkah laku dapat terjadi dalam berbagai kondisi berdasarkan penjelasan dari para ahli 
pendidikan dan psikologi (Pane dan Dasopang, 2017).

Berdasarkan uraian di atas dapat disintesiskan bahwa perilaku belajar adalah suatu aktivitas mental/psikis, yang berlangsung dalam interaksi aktif dengan lingkungan, yang menghasilkan perubahan-perubahan dalam pengetahuan pemahaman, ketrampilan dan nilai sikap, yang diukur berdasarkan indikator: (1) mengikuti pelajaran, (2) mengulangi pelajaran, (3) membaca buku, (4) mengunjungi perpustakaan, dan (5) menghadapi ujian.

\section{Penelitian Terdahulu yang Relevan}

Berikut ini dipaparkan hasil penelitian yang relevan dengan masalah yang dibahas dalam penelitian ini. Pertama, beberapa penelitian tentang pengaruh kebijakan pembelajaran terhadap perilaku belajar. Penelitian yang dilakukan Suryaningsih dan Poerwati (2021). Tujuan penelitiannya adalah untuk mengetahui pengaruh penerapan pembelajaran kooperatif tipe jigsaw terhadap perilaku kesehatan dan keselamatan anak usia dini. Penelitian serupa dilakukan Hendrayani dan Arief (2018). Tujuan penelitiannya adalah untuk mengetahui pengaruh strategi pembelajaran serta efikasi diri terhadap hasil belajar PKn. Selanjutnya penelitian yang dilakukan Jamil dan Aprilisanda (2020). Tujuan penelitiannya adalah untuk mengetahui apakah pembelajaran daring yang dilaksanakan oleh dosen di INSTIKA dan UPN Jatim dapat meningkatkan minat belajar mahasiswa terhadap mata kuliah yang diampu. Kemudian penelitian yang dilakukan Jusuf, dkk (2020). Tujuan dari penelitian untuk memperoleh gambaran pelaksanaan pembelajaran jarak jauh bagi siswa SMANU M.H. Thamrin sebagai upaya menekan penyebaran covid-19 di lingkungan sekolah.

Kedua, beberapa penelitian
tentang
pembelajaran terhadap efikasi diri. Penelitian yang dilakukan Oktalia dkk., (2017). Tujuan penelitiannya adalah untuk mengetahui pengaruh interaksi antara model pembelajaran dan efikasi diri terhadap prestasi belajar ekonomi. Dipihak lain penelitian dilakukan Mahayukti dkk., (2020). Tujuan dari penelitiannya adalah untuk mengkaji apakah pembelajaarn berbasis masalah dengan penilaian diri berpengaruh terhadap efikasi diri dan hasil belajar mahasiswa.

Ketiga, beberapa penelitian tentang pengaruh efikasi diri terhadap perilaku belajar. Penelitian yang dilakukan Pratiwi dan Hayati (2021). Tujuan dari penelitian ini adalah untuk mengetahui apakah ada pengaruh yang signifikan antara efikasi diri terhadap prestasi belajar mahasiswa. Penelitian serupa juga dilakukan Ningsih dan Hayati (2020). Tujuan penelitiannya untuk melihat dampak efikasi diri terhadap proses dan hasil belajar matematika. Selanjutnya penelitian yang dilakukan Yoenanto (2017). Tujuan dari penelitian ini adalah untuk membuktikan secara empiris apakah ada pengaruh yang signifikan antara efikasi diri dan dukungan sosial guru terhadap prestasi belajar matematika pada siswa jenjang SMP di Surabaya. Kemudian penelitian yang dilakukan Witurrachmi dan Hamidi (2017). Penelitian ini bertujuan untuk menguji pengaruh efikasi diri dan perilaku belajar terhadap prestasi belajar.

\section{METODE}

Penelitian ini menggunakan pendekatan kuantitatif dengan metode korelasional. Pendekatan kuantitatif merupakan salah satu jenis penelitian 
yang spesifikasinya adalah sistematis, terencana dan terstruktur dengan jelas sejak awal hingga pembuatan desain penelitiannya (Sugiyono, 2018).

Populasi dalam penelitian ini yaitu seluruh siswa kelas XI dan kelas XII SMK Negeri 1 Pekanbaru yang berjumlah 828 siswa. Pilihan siswa kelas XI dan XII dilatari oleh pertimbangan bahwa siswa tersebut sudah mengalami pembelajaran jarak jauh pada masa pandemi minimal satu tahun. Rincian populasi adalah sebagai berikut:

Tabel 1 Populasi penelitian

\begin{tabular}{ccc}
\hline No. & Nama Kelas & Jumlah Siswa \\
\hline 1 & Kelas XI & 432 \\
2 & Kelas XII & 396 \\
& Jumlah & 828 \\
\hline
\end{tabular}

Sumber: Data diolah oleh Peneliti

Untuk populasi 828, menurut formula Slovin (dalam Widodo, 2019) dengan error margin $0,1 \quad(10 \%)$ diperlukan sampel penelitian dengan perhitungan sebagai berikut:

$$
\mathrm{n}=\frac{\mathrm{N}}{1+\mathrm{N}(\mathrm{e})^{2}}
$$

Keterangan:

$\mathrm{n}=$ Ukuran sampel

$\mathrm{N}=$ Ukuran populasi

$\mathrm{e}=$ Error margin

$$
\mathrm{n}=\frac{828}{1+}
$$$$
\mathrm{n}=\frac{828}{1+}
$$$$
\mathrm{n}=828 / 9,28
$$$$
\mathrm{n}=89
$$

Merujuk pada perhitungan tersebut, maka jumlah sampel penelitian ini adalah 89 orang. Pengambilan sampel dilakukan secara acak sederhana (simple random sampling).

Metode pengumpulan data variabel kebijakan pembelajaran, efikasi diri, dan perilaku belajar siswa SMK Negeri 1 Pekanbaru adalah kuesioner dalam bentuk skala Likert. Dalam skala ini pernyataan-pernyataan yang diajukan terdiri dari lima alternatif jawaban, yaitu: Sangat Setuju/Selalu = 5 , Setuju/Sering $=4$, Ragu-ragu/Jarang $=3$, Tidak Setuju/Kadang-kadang $=2$, dan Sangat Tidak Setuju/Tidak Pernah $=1$.

Kuesioner sebelum digunakan untuk penelitian terlebih dahulu diujicobakan ke sebagian populasi yang bukan merupakan sampel untuk mengetahu validitas dan reliabilitasnya.

Berdasarkan hasil uji reliabilitas diperoleh nilai Cronbach's Alpha sebesar 0,878 >0,60, sehingga variabel perilaku belajar adalah reliabel. Dengan demikian variabel perilaku belajar yang terdiri dari 15 butir pernyataan valid dan reliabel sehingga layak digunakan untuk melakukan penelitian.

Penelitian ini akan menggunakan metode analisis data dengan tiga tahapan analisis, yakni:

1. Tahap analisis statistika deskriptif Tahap analisis statistika deskriptif meliputi: mean, median, modus, standar deviasi, varians, skor maksimum dan minimum, rentang (range), distribusi frekuensi, dan histrogram.

2. Tahap uji persyaratan analisis (uji asumsi klasik).

3. Tahap uji hipotesis dengan analisis jalur (path analysis).

\section{HASIL DAN PEMBAHASAN}

Dalam hasil dan pembahasan data yang diperoleh dari hasil penyebaran kuesioner terhadap 89 responden adalah sebagai berikut. 


\section{Kebijakan Pembelajaran}

Berdasarkan hasil analisis data, distribusi frekuensi skor variabel kebijakan pembelajaran adalah sebagai berikut:

Tabel 2. Distribusi frekuensi skor kebijakan pembelajaran

\begin{tabular}{cccccc}
\hline \multirow{2}{*}{ No } & \multirow{2}{*}{ Kelas } & \multicolumn{2}{c}{ Frekuensi } & \multicolumn{2}{c}{ Batas Nyata } \\
\cline { 3 - 6 } & Interval & Absolut & $\begin{array}{c}\text { Relatif } \\
(\mathbf{\%})\end{array}$ & Bawah & Atas \\
\hline 1 & $16-20$ & 2 & 2,2 & 15,5 & 20,5 \\
2 & $21-25$ & 3 & 3,3 & 20,5 & 25,5 \\
3 & $26-30$ & 13 & 14,5 & 25,5 & 30,5 \\
4 & $31-35$ & 29 & 32,5 & 30,5 & 35,5 \\
5 & $36-40$ & 32 & 35,9 & 35,5 & 40,5 \\
6 & $41-45$ & 5 & 5,6 & 40,5 & 45,5 \\
7 & $46-50$ & 5 & 5,6 & 45,5 & 50,5 \\
& & $\mathbf{8 9}$ & $\mathbf{1 0 0}$ & - & - \\
\hline & & & Distribusi & frekuensi & skor
\end{tabular}

variabel kebijakan pembelajaran sebagian besar pada interval $36-40$ yaitu $35,9 \%$, diikuti data pada interval 31 - 35 sebesar 32,5\%, 26 - 30 sebesar $14,5 \%, 41-45 \& 46-50$ sebesar 5,6\%, $21-25$ sebesar $3,3 \%$, dan $15-20$ sebesar 2,2\%. Gambaran lebih jelasnya mengenai distribusi frekuensi variabel kebijakan pembelajaran dapat dilihat pada Gambar 1.

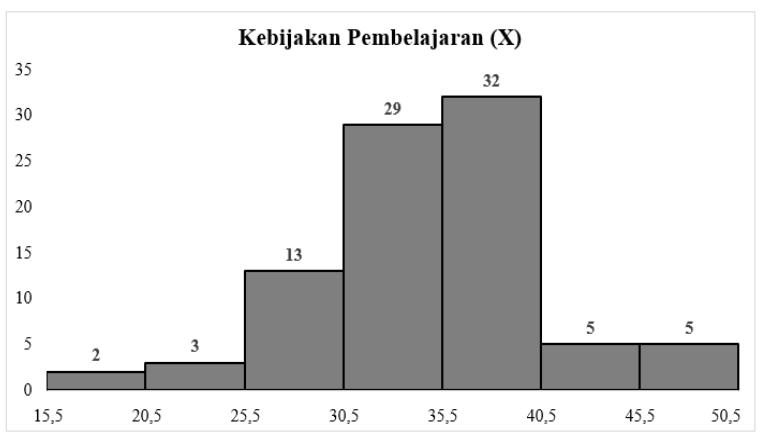

Gambar 1. Kebijakan pembelajaran

\section{Efikasi Diri}

Hasil penelitian menunjukkan skor terendah 30 dan tertinggi adalah
55. Dengan demikian rentang datanya adalah $25(55-30)$. Nilai rata-rata $=$ 42,60 , mode $=44$, median $=43,00$, std. deviation $=5,666$, dan variance-nya sebesar 32,107. Pada Tabel 3 ditunjukkan distribusi frekuensi skor variabel efikasi diri sebagai berikut.

Tabel 3. Distribusi skor efikasi diri

\begin{tabular}{|c|c|c|c|c|c|}
\hline \multirow[t]{2}{*}{ No } & \multirow{2}{*}{$\begin{array}{c}\text { Kelas } \\
\text { Interval }\end{array}$} & \multicolumn{2}{|c|}{ Frekuensi } & \multicolumn{2}{|c|}{ Batas Nyata } \\
\hline & & Absolut & $\begin{array}{c}\text { Relatif } \\
(\%)\end{array}$ & Bawah & Atas \\
\hline 1 & $30-33$ & 6 & 6,6 & 29,5 & 33,5 \\
\hline 2 & $34-37$ & 10 & 11,1 & 33,5 & 37,5 \\
\hline 3 & $38-41$ & 18 & 20,2 & 37,5 & 41,5 \\
\hline 4 & $42-45$ & 30 & 33,7 & 41,5 & 45,5 \\
\hline 5 & $46-49$ & 17 & 19,1 & 45,5 & 49,5 \\
\hline 6 & $50-53$ & 4 & 4,4 & 49,5 & 53,5 \\
\hline 7 & $54-57$ & 4 & 4,4 & 53,5 & 57,5 \\
\hline \multicolumn{2}{|c|}{ Jumlah } & 89 & 100 & - & - \\
\hline
\end{tabular}

Distribusi frekuensi skor efikasi diri paling besar adalah 33,7\% terletak pada interval $42-45,20,2 \%$ terletak pada interval $38-41,19,1 \%$ pada interval $46-49,11,1 \%$ pada interval 34 - 37, 6,6\% terletak pada interval $30-$ 33, dan 4,4\% terletak pada interval 50 $53 \& 54-57$. Gambaran lebih jelasnya mengenai distribusi frekuensi efikasi diri dapat dilihat pada Gambar 2.

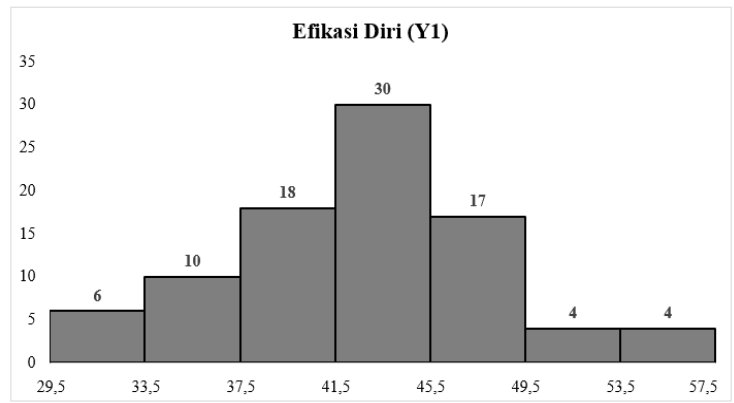

Gambar 2. Efikasi diri 


\begin{tabular}{lc}
$\begin{array}{c}\text { Tabel 6. Rangkuman } \\
\text { multikolinearitas }\end{array}$ & hasil \\
\hline DESKRIPSI & $\begin{array}{c}\text { HASIL } \\
\text { PERHITNGAN } \\
\text { STATISTIK }\end{array}$ \\
\hline X terhadap Y2 & \\
Nilai Tolerance & 1,000 \\
Nilai VIF & 1,000 \\
Y1 terhadap Y2 & \\
Nilai Tolerance & 1,000 \\
Nilai VIF & 1,000 \\
X terhadap Y1 & \\
Nilai Tolerance & 1,000 \\
Nilai VIF & 1,000 \\
\hline
\end{tabular}

Dari hasil di atas terlihat bahwa untuk semua pengaruh antar variabel tidak terjadi multikolinearitas karena diperoleh nilai tolerance $(1,000)$ lebih besar 0,10 , dan nilai VIF $(1,000)$ lebih kecil dari 10,00.

Hasil perhitungan koefisien jalur dan uji $t$ untuk menguji hipotesis pengaruh langsung kebijakan pembelajaran terhadap perilaku belajar disajikan pada tabel berikut.

Tabel 7. Koefisien jalur dan thitung pengaruh langsung kebijakan pembelajaran terhadap perilaku belajar

\begin{tabular}{|c|c|c|c|c|}
\hline \multirow{2}{*}{$\begin{array}{l}\text { Jumlah } \\
\text { Sampel } \\
\text { (n) }\end{array}$} & \multirow{2}{*}{$\begin{array}{c}\text { Koefisien } \\
\text { Jalur }\end{array}$} & \multirow[b]{2}{*}{ thitung } & \multicolumn{2}{|c|}{$\mathbf{t}_{\text {tabel }}$} \\
\hline & & & $\begin{array}{c}\alpha= \\
0,05\end{array}$ & $\begin{array}{c}\alpha= \\
0,01\end{array}$ \\
\hline 89 & 0,255 & $2,775 * *$ & 1,662 & 2,368 \\
\hline
\end{tabular}

** Koefisien jalur sangat signifikan ( thitung $=2,775$ > $t_{\text {tabel }} 2,368$ pada $\alpha=0,01$ )

Koefisien jalur pengaruh langsung kebijakan pembelajaran terhadap perilaku belajar sebesar 0,255. Koefisien jalur bernilai positif sehingga menunjukkan bahwa perbaikan kebijakan pembelajaran dapat menyebabkan peningkatan perilaku belajar. Sementara itu nilai thitung yang diperoleh sebesar 2,775, sedangkan nilai $\mathrm{t}_{\text {tabel }}$ untuk $\mathrm{n}=89$ pada tingkat kesalahan

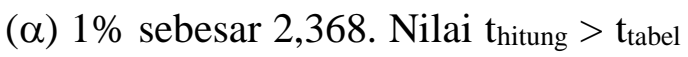
pada $\alpha=0,01$ (1\%) yang berarti Ho ditolak dan $\mathrm{H}_{1}$ diterima. Dengan demikian, kebijakan pembelajaran berpengaruh langsung positif dan sangat signifikan terhadap perilaku belajar.

\section{Pengaruh Langsung Efikasi Diri terhadap Perilaku Belajar}

Hasil perhitungan koefisien jalur dan uji $t$ untuk menguji hipotesis pengaruh langsung efikasi diri terhadap perilaku belajar disajikan pada tabel berikut.

Tabel 8. Koefisien jalur dan thitung pengaruh langsung efikasi diri terhadap perilaku belajar

\begin{tabular}{|c|c|c|c|c|}
\hline \multirow{2}{*}{$\begin{array}{c}\text { Jumlah } \\
\text { Sampel } \\
\text { (n) }\end{array}$} & \multirow{2}{*}{$\begin{array}{c}\text { Koefisien } \\
\text { Jalur }\end{array}$} & \multirow[b]{2}{*}{ thitung $_{\text {hit }}$} & \multicolumn{2}{|c|}{$\mathbf{t}_{\text {tabel }}$} \\
\hline & & & $\begin{array}{c}\alpha= \\
0,05\end{array}$ & $\begin{array}{c}\alpha= \\
0,01\end{array}$ \\
\hline 89 & 0,597 & $8,169 * *$ & 1,662 & 2,368 \\
\hline
\end{tabular}

$* *$ Koefisien jalur sangat signifikan (thitung $=8,169>$ $t_{\text {tabel }} 2,368$ pada $\alpha=0,01$ )

Koefisien jalur pengaruh langsung efikasi diri terhadap perilaku belajar sebesar 0,597. Koefisien jalur bernilai positif sehingga menunjukkan bahwa perbaikan efikasi diri dapat menyebabkan peningkatan perilaku belajar. Sementara itu nilai thitung yang diperoleh sebesar 8,169 , sedangkan nilai $\mathrm{t}_{\text {tabel }}$ untuk $\mathrm{n}=89$ pada tingkat kesalahan

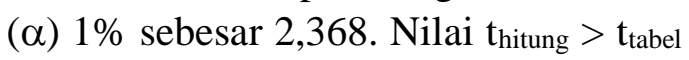
pada $\alpha=0,01(1 \%)$ yang berarti Ho ditolak dan $\mathrm{H}_{1}$ diterima. Dengan demikian, efikasi diri berpengaruh langsung positif dan sangat signifikan terhadap perilaku belajar.

\section{Pengaruh Langsung Kebijakan Pembelajaran terhadap Efikasi Diri \\ Hasil perhitungan koefisien jalur dan uji $\mathrm{t}$ untuk menguji hipotesis pengaruh langsung kebijakan pembelajaran terhadap efikasi diri disajikan pada Tabel 9.}


Tabel 9. Koefisien jalur dan thitung pengaruh langsung kebijakan pembelajaran terhadap efikasi diri

\begin{tabular}{|c|c|c|c|c|}
\hline \multirow{2}{*}{$\begin{array}{c}\text { Jumlah } \\
\text { Sampel } \\
\text { (n) }\end{array}$} & \multirow[b]{2}{*}{$\begin{array}{c}\text { Koefisien } \\
\text { Jalur }\end{array}$} & \multirow[b]{2}{*}{$\mathbf{t}_{\text {hitung }}$} & \multicolumn{2}{|c|}{$\mathbf{t}_{\text {tabel }}$} \\
\hline & & & $\begin{array}{c}\alpha= \\
0,05\end{array}$ & $\begin{array}{c}\alpha= \\
0,01\end{array}$ \\
\hline 89 & 0,458 & $4,683^{* *}$ & 1,662 & 2,368 \\
\hline
\end{tabular}
langsung kebijakan pembelajaran terhadap efikasi diri sebesar 0,458. Koefisien jalur bernilai positif sehingga menunjukkan bahwa perbaikan kebijakan pembelajaran dapat meningkatkan efikasi diri. Sementara itu nilai $t_{\text {hitung }}$ yang diperoleh sebesar 4,683 , sedangkan nilai $t_{\text {tabel }}$ untuk $n=89$ pada tingkat kesalahan $(\alpha) 1 \%$ sebesar 2,368 . Nilai $t_{\text {hitung }}>t_{\text {tabel }}$ pada $\alpha=0,01$ (1\%) yang berarti Ho ditolak dan $\mathrm{H}_{1}$ diterima. Dengan demikian, kebijakan pembelajaran berpengaruh langsung positif dan sangat signifikan terhadap efikasi diri.

\section{Pengaruh Tidak Langsung Kebijakan} Pembelajaran terhadap Perilaku Belajar dengan Mediasi Efikasi Diri

Hasil perhitungan koefisien jalur dan uji $t$ untuk menguji hipotesis pengaruh tidak langsung kebijakan pembelajaran terhadap perilaku belajar dengan mediasi efikasi diri disajikan pada Tabel 10.

Tabel 10. Koefisien jalur dan $t_{\text {hitung }}$ pengaruh tidak langsung kebijakan pembelajaran terhadap perilaku belajar dengan mediasi efikasi diri

\begin{tabular}{ccccc}
\hline Jumlah Sampel (n) & $\begin{array}{c}\text { Koefisien } \\
\text { Jalur }\end{array}$ & $\mathbf{t}_{\text {hitung }}$ & $\begin{array}{c}\boldsymbol{\alpha}= \\
\mathbf{0 , 0 5}\end{array}$ & $\begin{array}{c}\mathbf{\alpha =} \\
\mathbf{0 , 0 1}\end{array}$ \\
\hline 89 & 0,274 & $3,775^{* *}$ & 1,662 & 2,368
\end{tabular}

$* *$ Koefisien jalur sangat signifikan ( $t_{\text {hitung }}=3,775$ $>t_{\text {tabel }} 2,368$ pada $\alpha=0,01$ )
Koefisien jalur pengaruh tidak langsung kebijakan pembelajaran terhadap perilaku belajar dengan mediasi efikasi diri sebesar 0,274. Koefisien jalur bernilai positif sehingga menunjukkan bahwa perbaikan kebijakan pembelajaran dengan didukung efikasi diri dapat meningkatkan perilaku belajar. Sementara itu nilai thitung yang diperoleh sebesar 3,775, sedangkan nilai tabel untuk $n=89$ pada tingkat kesalahan $(\alpha)$ $1 \%$ sebesar 2,368 . Nilai $t_{\text {hitung }}>t_{\text {tabel }}$ pada $\alpha=0,01(1 \%)$ yang berarti Ho ditolak dan $\mathrm{H}_{1}$ diterima. Dengan demikian, kebijakan pembelajaran berpengaruh tidak langsung positif dan sangat signifikan terhadap perilaku belajar dengan mediasi efikasi diri.

Keseluruhan hasil koefisien jalur dan uji $t$ pengaruh kebijakan pembelajaran terhadap efikasi diri dan perilaku belajar dirangkum pada tabel berikut.

Tabel 11. Rangkuman koefisien jalur dan uji $t$

\begin{tabular}{|c|c|c|c|c|}
\hline \multirow{2}{*}{ Jalur } & \multirow{2}{*}{$\begin{array}{c}\text { Koefisien } \\
\text { Jalur }\end{array}$} & \multirow{2}{*}{$\mathbf{t}_{\text {hitung }}$} & \multicolumn{2}{|c|}{$\mathbf{t}_{\text {tabel }}$} \\
\hline & & & $\begin{array}{c}\alpha= \\
0,05\end{array}$ & $\begin{array}{c}\alpha= \\
0,01\end{array}$ \\
\hline $\mathrm{X} 1-\mathrm{Y} 1$ & 0,255 & $2,775 * *$ & 1,662 & 2,368 \\
\hline $\mathrm{X} 2-\mathrm{Y} 1$ & 0,597 & $8,169 * *$ & 1,662 & 2,368 \\
\hline $\mathrm{X} 1-\mathrm{Y} 2$ & 0,458 & $4,683 * *$ & 1,662 & 2,368 \\
\hline$\frac{\mathrm{X}-\mathrm{Y} 2-}{\mathrm{Y} 1}$ & 0,274 & $3,775 * *$ & 1,662 & 2,368 \\
\hline
\end{tabular}

\section{Pembahasan}

Hasil penelitian ini menunjukan bahwa kebijakan pembelajaran berpengaruh positif dan sangat signifikan terhadap perilaku belajar. Perilaku belajar yang baik bagi siswa sekolah disaat masa pandemi Covid-19 merupakan harapan dan tujuan yang 
ingin dicapai oleh semua pihak, baik siswa, guru maupun orangtua. Untuk mencapai perilaku belajar yang baik tersebut diperlukan sejumlah faktor yang dapat mendukungnya. Salah satu faktor yang dapat mendukungnya adalah kebijakan pembelajaran. Hasil penelitian Suryaningsih dan Poerwati (2021), Hendrayani dan Arief (2018), Jamil dan Aprilisanda (2020), serta Jusuf dkk., (2020) juga menunjukkan bahwa kebijakan pembelajaran yang dipaplikasi dengan berbagai cara dapat meiningkatkan perilaku belajar sehingga menghasilkan prestasi/hasil belajar yang lebih baik. Dengan demikian, temuan ini konsisten dan mengnonfirmasi hasil penelitian sebelumnya bahwa kebijakan pembelajaran berpengaruh terhadap perilaku belajar dengan setting siswa SMK Negeri 1 Pekanbaru.

Hasil penelitian ini juga membuktikan bahwa efikasi diri berpengaruh positif dan sangat signifikan terhadap perilaku belajar. Hasil penelitian terdahulu yang dilakukan Pratiwi dan Hayati (2021), Ningsih dan Hayati (2020), serta Yoenanto (2017) juga membuktikan bahwa efikasi diri berpengaruh terhadap perilalu (hasil) belajar. Dengan demikian, temuan ini selaras dan mengonfirmasi hasil penelitian sebelumnya bahwa efikasi diri berpengaruh terhadap perilaku belajar dengan setting siswa SMK Negeri 1 Pekanbaru.

Hasil penelitian ini juga memperlihatkan bahwa kebijakan pembelajaran berpengaruh positif dan sangat signifikan terhadap efikasi diri. Hal ini mengindikasikan bahwa perbaikan impelementasi kebijakan pembelajaran dapat meningkatkan efikasi diri siswa, khususnya kebijakan pembelajaran yang diberlakukan pada masa pandemi Covid-19. Hasil penelitian Oktalia dkk., (2017) serta Mahayukti dkk., (2020) juga menunjukkan bahwa kebijakan pembelajaran berpengaruh terhadap efikasi diri. Dengan demikian, temuan ini konsisten dan mengonsfirmasi hasil penelitian terdahulu bahwa kebijakan pembelajaran berpengaruh terhadap efikasi diri dengan setting siswa SMK Negeri 1 Pekanbaru.

Selain itu, hasil penelitian ini juga membuktikan bahwa kebijakan pembelajaran berpengaruh tidak langsung positif dan sangat signifikan terhadap perilaku belajar dengan mediasi efikasi diri. Temuan ini semakin memperkokoh dan mendukung hasil penelitian terdahulu yang dijadikan dasar untuk membangun hipotesis penelitian ini dan sekaligus membuktikan peranan efikasi diai dalam memediasi pengaruh kebijakan pembelajarn terhadap perilaku belajar dengan setting siswa SMK Negeri 1 Pekanbaru.

\section{KESIMPULAN}

Hasil penelitian ini membuktikan bahwa kebijakan pembelajaran berpengaruh terhadap perilaku belajar, baik secara langsung maupun tidak langsung dengan mediasi efikasi diri. Hal ini menunjukkan vitalitas efikasi diri dalam mediasi pengaruh kebijakan pembelajaran terhadap perilaku belajar siswa, sehingga diperlukan penelitian lanjutan untuk mengonfirmasi temuan tersebut dengan kancah (obyek) yang berbeda.

Kebijakan pembelajaran berpengaruh terhadap efikasi diri dan perilaku belajar siswa. Hal ini memberikan konsekuensi bahwa sekolah secara terus menerus perlu memperbaiki kebijakan pembelajaran dan mengimplementasikannnya sebaik mungkin agar memberikan dampak yang lebih besar terhadap efikasi diri 
dan perilaku belajar siswa, sehingga kemudian berimplikasi pada peningkatan prestasi belajar siswa dan kualitas pendidikan.

Berdasarkan kesimpulan tersebut, perlu dilakukan penelitian lanjutan dengan sampel yang berbeda dan jumlah yang lebih besar serta menggunakan teknik analisis yang berbeda, misalnya: stuctutral equation modeling (SEM) dan dengan menggunakan software yang berbeda, misalnya LiSrel.

\section{DAFTAR PUSTAKA}

Aunurrahman. (2013). Belajar dan Pembelajaran. Bandung: Alfabeta.

GTK Kemendikbudristek. (2020). Kebijakan Kemendikbud di Masa Pandemi, Sekretariat GTK, 03 September.

Handoyo, E. (2012). Kebijakan Publik. Semarang: Widya Karya.

Hendrayani, E., dan Arief, Z. A. (2018). "Pengaruh Strategi Pembelajaran dan Efikasi Diri terhadap Hasil Belajar Siswa pada Mata Pelajaran Pendidikan Kewarganegaraan di SMP PGRI Gunung Picung Pamijahan," Jurnal Teknologi Pendidikan, 7(2), 187-206.

Jamil, S. H., dan Aprilisanda, I. D. (2020). "Pengaruh Pembelajaran Daring terhadap Minat Belajar Mahasiswa pada Masa Pandemik Covid-19," BAJ (Behavioral Accounting Journal), 3(1), 37-46.

Jusuf, H, Sobari, A., dan Fathoni, M. (2020). "Pengaruh Pembelajaran Jarak Jauh bagi Siswa SMA Di Era Covid-19," Jurnal Kajian Ilmiah (JKI), (1), 15-24.

Luthans, F. (2013). Organizational Behavior. New York: McGrawHill Companies, Inc.
Mahayukti, G. A., Dewi, P. K, dan Hartawan, I G. N. Y.. (2020). "Pengaruh Pembelajaran Berbasis Masalah dengan Penilaian Diri terhadap Efikasi Diri dan Hasil Belajar Mahasiswa," ANARGYA: Jurnal Ilmiah Pendidikan Matematika, 3(2), 88-95.

Munir. (2012). Multimedia Konsep dan Aplikasi dalam Pendidikan. Bandung: Alfabeta.

Ningsih, W. F., dan Hayati, I. R. (2020). "Dampak Efikasi Diri Terhadap Proses dan Hasil Belajar Matematika," Journal on Teacher Education (JOTE), 1(2), 26-32.

Nugroho, R. (2014). Kebijakan Publik di Negara-Negara Berkembang. Yogyakarta: Pustaka Pelajar.

Oktalia, H., Sapri, J. dan Turdjai. (2017). "Pengaruh Model Pembelajaran Dan Efikasi Diri Terhadap Prestasi Belajar Ekonomi (Studi Eksperimen pada Mata Pelajaran Ekonomi Siswa Kelas XI IPS MA di Bengkulu Tengah)," DIADIK: Jurnal Ilmiah Teknologi Pendidikan, 7(2), 3847.

Pane, A. dan Dasopang, M. D. (2017). "Belajar dan Pembelajaran," FITRAH Jurnal Kajian Ilmu-ilmu Keislaman, 3(2), 333-352.

Permatasari, N., Sutanto, L., dan Ismail, N. S. (2021). "Hubungan Efikasi Diri terhadap Tingkat Kejenuhan Akademi: Studi Empiris Pembelajaran daring Semasa COVID-19," Jurnal Sosio Sains, 7,(1), 36-50.

Pratiwi, I. W., dan Hayati. (2021). "Efikasi Diri dan Pengaruhnya Terhadap Prestasi Belajar Mahasiswa," Jurnal Ilmiah Ilmu Sosial dan Humaniora, 7(1), 1523.

Rahmawati, Z. D. (2020). "Penggunaan Media Gadget dalam Aktivitas 
Belajar dan Pengaruhnya terhadap Perilaku Anak," Jurnal Studi Pendidikan Islam, 3(1), 97-113.

Siswanto, H., Yundy dan Antoh, A. (2016). "Pengaruh Transparansi Kebijakan Publik Terhadap Pengetahuan Dewan Tentang Anggaran dengan Partisipasi Masyarakat SebagaiVariabel Moderasi," Jurnal Kajian Ekonomi dan Keuangan Daerah, 1(2), 51-82.

Sugiyono. (2018). Metode Penelitian Kuantitatif. Bandung: Alfabeta.

Suryaningsih, N. M A., dan Poerwati, C. E. (2021). "Pengaruh Penerapan Pembelajaran Kooperatif Tipe Jigsaw terhadap Perilaku Kesehatan dan Keselamatan Anak," Jurnal Obsesi: Jurnal Pendidikan Anak Usia Dini, 5(2), 1063-1072.

Suwitri, S. (2014). Analisis Kebijakan Publik. Jakarta: Universitas Terbuka.

Widodo. (2019). Metodologi Penelitian Populer dan Praktis, Depok: Rajawali Pers.

Witurrachmi, L. S., dan Hamidi, N. (2017). "Pengaruh Efikasi Diri Dan Perilaku Belajar Terhadap Prestasi Belajar Siswa SMK di Karanganyar," Jurnal Tata Arta UNS, 3(1), 189-198.

Yerusalem, M. R., Rochim, A. F., dan Martono, K. T. (2020). "Desain dan Implementasi Sistem Pembelajaran Jarak Jauh Di Program Studi Sistem Komputer," Jurnal Teknologi dan Sistem Komputer, 3(4), 481-492.

Yoenanto, N. H. (2017). "Pengaruh Efikasi Diri dan Dukungan Sosial Guru Terhadap Prestasi Belajar Matematika pada Siswa SMP di Surabaya," Prosiding Tети Ilmiah $X$ Ikatan Psikologi
Perkembangan Indonesia, 1(1), 89-99. 